\title{
THEMATIC PATTERNING TECHNIQUE ON WRITING ACHIEVEMENT AND ITS RELATIONSHIP TO ACHIEVEMENT MOTIVATION OF THE STUDENTS OF ENGLISH EDUCATION DEPARTMENT GANESHA UNIVERSITY OF EDUCATION
}

\author{
Juniarta, P. A. K. \\ English Language Education \\ Ganesha University of Education \\ Singaraja, Indonesia \\ e-mail: adiputu108@gmail.com
}

\begin{abstract}
This study aimed at investigating the effect of thematic patterning technique and achievement motivation on students' writing achievement. The subjects were the second semester students of English Education Department in the academic year 2015/2016 recruited by using cluster random sampling. The population was 7 classes, 2 classes were taken as the sample of the study. The total number of sample was 52 students who were divided into four cells of treatments. The II B class was assigned as the experimental group and II D class as the control group. The experimental group was taught by using thematic patterning technique and the control group by using conventional technique. The research design was post test only control group design by using $2 \times 2$ factorial design. There were three variables in this study, namely: independent, moderator, and dependent variables. The independent variable was thematic patterning technique and moderator variable was the students' achievement motivation level (high and low). In another side, students' achievement in writing paragraph was categorized as dependent variable. The instrument that was used to test the students' achievement motivation was achievement motivation questionnaire, while the instrument used to test students' writing achievement was writing achievement test. The analysis of data used two way Anova and then continued by post hoc testing using Tukey test. The findings of the study were: there was a significant difference in writing achievement between the students who are taught by using thematic patterning technique and those who are taught by using conventional technique. The mean score of students taught by using thematic patterning technique was higher than the mean score of students' writing achievement for students taught by using conventional technique, there was interaction between of thematic patterning technique and the achievement motivation in learning English on students' writing achievement.
\end{abstract}

Keywords: thematic patterning technique, achievement motivation, students' writing achievement.

\section{INTRODUCTION}

Communication is an act or instance of transmitting or a process whereby we attempt to transmit our thought, ideas, wishes, or emotions to others. The power of communication and global networks are the keys which lead the people to compete in global chance. Language is not only a means of communication but also a medium to share and to express ourselves. Being able to communicate feelings, ideas, and thought is the essential part in our life. Mastering international language is an important thing as to widen our knowledge of the world and to take a part in global change. In the very tight competition of global change, those who can survive are people who are able to cooperate with others, think critically, are skillful and creative, understand cultures, communicate well, and are able to learn independently.

As an international language, English is a medium of interaction and communication among people from different parts of the world. Being competent in English is now becoming one of the essential needs. The four language skills, namely listening, speaking, reading, and writing are used for 
practical purposes, as a medium to convey meanings and ideas. Those abilities must be seen as a whole ability because they are integrated with each others.

Furthermore, writing is one of the four language skills that should be mastered in order to master English well. Teaching writing aims to lead the students in achieving some competencies which require them to be capable in expressing their ideas in written form. The expectations that should be mastered by the students in writing skill are shown in the standard and basic competencies of writing. Standard competency of writing covers content standard and performance standard, which deal with knowledge, skill, attitude, and level comprehension. In the other hand, as the details of standard competency, basic competency is the knowledge, skill, and the minimum level that should be mastered and performed by the students in each standard. Further, to know whether or not the basic competency can be achieved by the students, some indicators should be formulated. The curriculum states that writing involves the achievement of both standard and basic competencies. Specifically for the second semester, the standard competency for writing is an ability to express meaning nuance with correct development of several written text/ genres, namely: narrative, descriptive, anecdote, news item, factual recount, simple exposition, and review using noun phrase with variation of structure modification. The standard competency is developed into several basic competencies that must be mastered by the students. The basic competencies in writing expect the students to be able to demonstrate basic writing skills (having competency in using grammar, punctuation, spelling, drafting, revising, and editing) and to produce various kinds of text, such as : narrative, descriptive, news item, analytic exposition, factual recount, and simple exposition.

Since writing is a complex activity, it is considered difficult for the students to write good writing in short time (Marhaeni, 2005). According to Chakraverty and Gantum (2001) writing is a reflective activity that requires enough time to think about the specific topic, to analyze and to classify any background knowledge. It means writing integrates several processes, such as: finding topic, providing information to support the topic, classifying ideas, organizing ideas in logical sequence and implementing linguistics knowledge. From Marhaeni (2005) and Chakraverty and Gantum (2000) point of views, it is interfered that writing is a continuous process that needs several stages. Consequently, the students must be given ample time to finish their writing assignment. Therefore, students who engage in a writing activity tend to face many problems during the process of writing.

Most of the students find it difficult to develop ideas in their minds. Actually, they might have something to state in their mind, but they are often confused to express and develop their ideas into a good writing. It is such a common problem that is encountered by most of English teachers in teaching writing. Allen Campbell (Campbell, 2001:1) claims that the biggest problem that students have in writing is that they cannot put their ideas and facts into paper since they are afraid if their ideas cannot be written correctly in terms of grammar. This condition leads the students to state of anxiety. In addition, Chakraverty and Gautum (2000:1) state further that one of the students' problems is that they have difficulty in arranging information or ideas logically to achieve coherence in their writing, which is the foremost requirement in writing.

Based on observation conducted in English Education Department, it was found that the students faced difficulties in writing. They considered that writing was difficult subject. Most of the students were found to get low score in this subject. In the process of teaching and learning English as a foreign language (EFL), writing was placed at the last stage after three other English skills (Listening, Speaking, and Reading). Moreover, teaching writing was allocated just 2 school hours (100 minutes) in a week. In teaching writing, process writing approach has been implemented by the teacher in which the students were provided ample time to finish their writing assignments. In one session class ( 2 school hours), the teacher guide the students starting from pre-writing until drafting stages. After that, the students may take and finish their writing at home. At the end of allocated time, each student should produce a writing product and collect it to the lecturer.

In a relation to the above problem, it seems that the existence of writing techniques can help the students to look at the ideas organization in their writing becomes a very prominent demand. There are actually several techniques in writing that can be used to help the students in organizing ideas. Among those numerous techniques, a technique that is called Thematic Patterning seem to be gratifying technique in helping student to reach the competency of writing. 
Thematic Patterning technique is a technique that helps the students to look at the progression of information or ideas in their writing to form coherent writing (Alonso and McCabe, 2003:1). It provides students with three main types of patterns that help them to organize the flow of information that is stated in each sentence in their writing. In each pattern, there will be parts name Theme and Rheme respectively. Theme can be defined as the starting point of a sentence and Rheme is what the writer writes about that starting point (Downing, 2001:3). The arrangement of theme and rheme can determine the coherence of the students' writing. The three types of Thematic Patterning are simple linear pattern, constant pattern, and drives of hypertheme pattern.

Furthermore, some experts had proved the influences of Thematic Patterning strategy in teaching Writing. Thematic Patterning strategy has been proven to be helpful to improve the students' achievement in writing in the high school students (Ruspita, 2012). In addition, Jing (2014) also applied this strategy for high school students. He found that their students were more motivated in writing. This strategy gave opportunity to students to access their prior knowledge, learnt from teacher's modeling and the students gave their own feedback and more conversations among their friends.

In addition, in learning a foreign language, students' success in mastering the foreign language is not merely determined by language learning strategies applied or situation of learning in the classroom, but also language aptitude and motivation (Gardner, 2001). Aptitude is an innate factor brought genetically since the human was born; while motivation is learned and possibly changed through time resulted from the stimulus. Motivation can be defined as a desire to achieve a goal, combined with the energy to work toward that goal (Abisamra, 2002). In other words, motivation is a push that leads the humans to do something to reach their goals. In language learning, the goal, of course, is the mastery of the foreign language. Related to the thematic patterning technique that provides chance for the students look at the progression of information or ideas in their writing to reach excellent standard of the goal, it can be said that thematic patterning technique can enhance students' motivation in learning.

To sum up, there are two things which are said to have a great influence towards writing achievement, namely: the teaching strategies and motivation of the students in learning English. Therefore in this research, thematic patterning technique which may enhance students' motivation and achievement motivation as one of several motives in human lives were further investigated. Specifically, this research tried to find evidences on whether the implementation of thematic patterning technique and students' achievement motivation could give a significant effect on the students' writing achievement. The research was conducted in writing class of second semester student of English Education Department Undiksha in the academic year 2015/2016.

This research concerns on the effect of thematic patterning technique and achievement motivation on the students' writing achievement. The result of this research is expected to give two positive contributions, practically and theoretically. For practical purpose, this study is expected to give great contribution to the teaching and learning process as well as to improve the students' motivation in learning English. For theoretical purpose, this study is expected to give contribution to learning theories development of applying students-center approach in the classroom. Further, it is expected to give chance for the other researcher to conduct similar research.

\section{METHODS}

This research was designed in an experimental design called Post test only control-group design since the objectives of this research were to find out, first, the significant difference in writing achievement between students who are taught by using thematic patterning technique and by conventional technique, and second, to find out the interaction between the implementation of technique in teaching writing and achievement motivation in learning English. This research was done of the tenth year students of SMAN 4 Singaraja in the academic year 2010/2011. The subjects were the second semester student of English Education Department Undiksha in the academic year 2015/2016 recruited by using cluster random sampling. The population was 6 classes, 2 classes were taken as the sample of the study. The total number of sample was 65 students who were divided into four cells of treatments. The II B class was assigned as the experimental group and II D class as the control group. The experimental group was taught by using thematic patterning technique and the 
control group by using conventional technique. The research design was post test only control group design by using $2 \times 2$ factorial design. There were three variables in this study, namely: independent, moderator, and dependent variables. The independent variable was thematic patterning technique and moderator variable was the students' achievement motivation level (high and low). In another side, students' achievement in writing paragraph was categorized as dependent variable. The instrument that was used to test the students' achievement motivation was achievement motivation questionnaire, while the instrument used to test students' writing achievement was writing achievement test. The analysis of data used two way Anova and then continued by post hoc testing using Tukey test.

\section{FINDINGS AND DISCUSSION}

This study was aimed to find out the significant effect on writing achievement between the students who were taught by using Thematic Patterning technique and those who were taught by using Conventional technique by considering the students' achievement motivation and to find out any interaction between the implementation of Thematic Patterning technique and achievement motivation in learning English upon students' writing achievement.

Based on two-way ANOVA and post hoc testing, the findings were as follows:

The first finding showed, the value of $F_{A}$ was 388.774 while $F_{c v}(1 ; 48 ; 0.01)$ was 6.302 . Since $F_{A}$ higher than $\mathrm{F}_{\mathrm{cv}}$, then $\mathrm{H}_{0}(1)$ which stated 'there is no significant effect on students' writing achievement between the students taught by using thematic patterning technique and conventional technique", was rejected. It means that $\mathrm{H}_{1}$ (1) which stated "there is a significant effect in students' writing achievement between the students taught by using thematic patterning technique and conventional technique", was accepted. It can be concluded that there is a significant effect in students' writing achievement between students taught by using thematic patterning technique and conventional technique, where the mean score of students taught by using thematic patterning technique 83.5256 was higher than the mean score of students' writing achievement for students taught by using conventional technique 73.2906

The second finding showed the value of $\mathrm{F}_{\mathrm{AB}}$ on interactional effect was 17.976 while $\mathrm{F}_{\mathrm{cv}(1 ; 48 ; 0.01)}$ was 6.302. Since $\mathrm{F}_{\mathrm{AB}}$ was higher than $\mathrm{F}_{\mathrm{CV}}$, it means that the null hypothesis $\mathrm{H}_{0}(2)$ which stated "there is no significant interactional effect between teaching technique (thematic patterning technique and conventional technique) and students' achievement motivation towards the students' writing achievement", was rejected. It means that the alternative hypothesis $\mathrm{H}_{1}(2)$ which stated "there is a significant interactional effect between teaching technique (thematic patterning technique and conventional technique) and students' achievement motivation towards the students' writing achievement", was accepted. So it can be concluded that there is a significant interactional effect between teaching technique (thematic patterning technique and conventional technique) and students' achievement motivation towards the students' writing achievement.

The third finding showed the $\mathrm{Q}_{\mathrm{ob}}$ was 11.508496. The $\mathrm{Q}$ critical value should be based on three things, they are the level of significant $(\alpha)$, the number of means $(t)$, and the $\mathrm{df}$ within that can be seen in anova table (q). For this study, the $\mathrm{Q}$ critical value should be $\mathrm{Q}$ with $\mathrm{t}=4$ and $\mathrm{df}=48$. However since the $\mathrm{Q}$ table does not provide 48 degree of freedom, then 60 degree of freedom was used. From the $\mathrm{Q}$ table, the $\mathrm{Q}_{\mathrm{cv}(4 ; 60 ; 0.05)}$ was 3.74 and the $\mathrm{Q}_{\mathrm{cv}(4 ; 60 ; 0.01)}$ was 4.59. This means the $\mathrm{Q}_{\mathrm{ob}}$ was higher than the $\mathrm{Q}_{\mathrm{cv}}$ in both 0.05 and 0.01 level of significance, so $\mathrm{H}_{0}$ was rejected. Therefore, it can be concluded that there was a significant difference between the students with high achievement motivation taught by using thematic patterning technique and conventional technique. The students with high achievement motivation taught by using thematic patterning technique $(X=87.051308)$ showed higher achievement than those with conventional achievement $(X=74.615385)$.

The fourth finding showed the $\mathrm{Q}_{\mathrm{ob}}$ was 7.4350663. The $\mathrm{Q}$ critical value should be based on three things, they are the level of significant $(\alpha)$, the number of means $(t)$, and the df within that can be seen in anova table (q). For this study the $\mathrm{Q}$ critical value should be $\mathrm{Q}$ with $\mathrm{t}=43$ and $\mathrm{df}=56$. However since the $\mathrm{Q}$ table does not provide 56 degree of freedom, then 60 degree of freedom was used. From the $\mathrm{Q}$ table, the $\mathrm{Q}_{\mathrm{cv}(4 ; 60 ; 0.05)}$ was 3.74 and the $\mathrm{Q}_{\mathrm{cv}(4 ; 60 ; 0.01)}$ was 4.59. This means the $\mathrm{Q}_{\mathrm{ob}}$ was higher than the $\mathrm{Q}_{\mathrm{cv}}$ in both 0.05 and 0.01 level of significance, so $\mathrm{H}_{0}$ was rejected. Therefore, it can be concluded that there was a significant difference between the students with low achievement motivation taught by using thematic patterning technique and conventional technique. The students with low achievement 
motivation taught by using thematic patterning technique $(X=80)$ showed higher achievement than those with conventional achievement $(X=71.965769)$.

The fifth finding showed the $\mathrm{Q}_{\mathrm{ob}}$ was 6.5254464 . The $\mathrm{Q}$ critical value should be bsed on three things, they are the level of significant $(\alpha)$, the number of means $(t)$, and the df within that can be seen in anova table (q). For this study the $\mathrm{Q}$ critical value should be $\mathrm{Q}$ with $\mathrm{t}=43$ and $\mathrm{df}=56$. However since the $\mathrm{Q}$ table does not provide 56 degree of freedom, then 60 degree of freedom was used. From the $\mathrm{Q}$ table, the $\mathrm{Q}_{\mathrm{cv}(4 ; 60 ; 0.05)}$ was 3.74 and the $\mathrm{Q}_{\mathrm{cv}(4 ; 60 ; 0.01)}$ was 4.59. This means the $\mathrm{Q}_{\mathrm{ob}}$ was higher than the $\mathrm{Q}_{\mathrm{cv}}$ in both 0.05 and 0.01 level of significance, so $\mathrm{H}_{0}$ was rejected. Therefore, it can be concluded that there was a significant difference between the students with high achievement motivation and the students with low achievement motivation taught by using thematic patterning technique. The students with high achievement motivation taught by using thematic patterning technique $(X=87.051308)$ showed higher achievement than the students with low achievement motivation taught by using thematic patterning technique $(X=80)$.

The sixth finding showed the $\mathrm{Q}_{\mathrm{ob}}$ was 7.531. The $\mathrm{Q}$ critical value should be based on three things, they are the level of significant $(\alpha)$, the number of means $(t)$, and the $\mathrm{df}$ within that can be seen in anova table (q). For this study the $\mathrm{Q}$ critical value should be $\mathrm{Q}$ with $\mathrm{t}=43$ and $\mathrm{df}=56$. However, since the $\mathrm{Q}$ table does not provide 56 degree of freedom, then 60 degree of freedom was used. From the $\mathrm{Q}$ table, the $\mathrm{Q}_{\mathrm{cv}(4 ; 60 ; 0.05)}$ was 3.74 and the $\mathrm{Q}_{\mathrm{cv}(4 ; 60 ; 0.01)}$ was 4.59. This means the $\mathrm{Q}_{\mathrm{ob}}$ was higher than the $\mathrm{Q}_{\mathrm{cv}}$ in both 0.05 and 0.01 level of significance, so $\mathrm{H}_{0}$ was rejected. Therefore, it can be concluded that there was a significant difference between the students with high achievement motivation and the students with low achievement motivation taught by using conventional technique. The students with high achievement motivation taught by using thematic patterning technique $(X=74.615385)$ showed higher achievement than the students with high achievement motivation by thematic patterning technique $(X=71.965769)$.

The high English achievement was shown by the group of students with high achievement motivation taught by using thematic patterning technique. As has been explained above about the characteristics of students with high achievement motivation, the students with high achievement motivation really love an activity that can challenge them to express their fullest potential. Here, the writing is a challenging activity that could stimulate the students with high achievement motivation to keep on expressing their ideas. The students could create their writing independently by using their own ideas and critical thinking but at the same time they had to control their own writing quality. They were the creator of ideas and at came time the evaluator of their work. But they were guided along the process by the teacher and by using the writing rubrics. They should choose one patterns in thematic patterning technique in ordered to be able to write at their best. The next characteristic was innovative. It means that the people with high achievement motivation are always being creative and innovative. The writing activity really needs a creative and innovative ways of thinking. The best result of the writing will show the students' creative and innovative ideas in producing their writing. The more creative and innovative to produces the ideas, the better writing will be produced. Students with high achievement motivation work for their personal achievement not for other factor such as environment. It makes them gave their best effort to compose the piece of writing. The next characteristic is being responsible. Being responsible here as that people with a high achievement motivation are responsible to do the challenging task with their best effort. It means that in writing narrative, descriptive, and news item text, they will show the best effort. They will be able to write their best piece by having a great responsibility to finish their piece. The last thing is about the affective factor. They loved the process of exploring ideas and exploring the language learning that they used. It gives a great contribution towards the writing achievement.

In conventional technique, the students with high achievement motivation will try to involve in writing activity by doing their best. They are motivated to learn by undergoing the process. They are also responsible to their learning. Although in conventional instruction the students were not really stimulated to construct their own meaning, but the students with high achievement motivation can solve their problem. They have the characteristics of dynamic and innovative so they will find the best strategy to reach their goal of learning.

The conventional technique does not provide chance for the students look at the progression of information or ideas in their writing to form coherent writing as it can be found in thematic patterning 
technique. It also can not help the students in composing and revising their writing to produce writing that is coherent. The students can not know their strengths, progress, and weaknesses when producing their writing.

The students with low achievement motivation, on the other hand will be discouraged to have the writing process. The characteristics of students with low achievement motivation are the opposite of the students with high achievement motivation. They think that the process is not important, but the product is more important. It means that the students with low achievement motivation will never try the best effort to make the best achievement. The students with low achievement motivated needs to be stimulated by the interesting technique. In fact, the conventional technique does not really give an interesting atmosphere of learning. The teacher-centered style made the students unmotivated. They do not have time to know their strengths, progress, and weaknesses when producing their writing. They do not enjoy the process, they do not get the meaning of the learning process and at the end they do not find that the learning is useful and meaningful.

Therefore, the thematic patterning technique gives more benefit to the students with low achievement motivation rather than those who were taught by using conventional technique.

The discussion of all the results of hypothesis testing indicates there is close relationship among the writing achievement, teaching technique (thematic patterning technique and conventional technique), and achievement motivation. Writing is considered as cognitive and creative processes. Cognitive process is seen on how the students produce ideas and arrange those ideas as clear and interesting as possible so that the readers will understand clearly the writing product. A writer is also expected to create creative writing. The creative writing can be seen from the originality of the ideas. So, the writers should use their imagination to create creative writing. The creative writers are always able to maximize information coming from environment and use the information to inspire their writing so that they create new ideas.

Thematic patterning technique enables the students to make reflection on their strengths, progress, and weaknesses when producing their writing learning so that the students can monitor their learning progress. Besides that, the students are active learners in the learning process, rather than recipients of information since they are engaged in learning by doing. Those conditions will provide studentscentered learning and meaningful learning experiences for the students.

In another point, achievement motivation is a drive to reach excellent standard. High achievement motivated students like new and challenging things. Moreover, they usually set goal of their task in learning. Therefore, high achievement motivated students need new things (e.i. feedback) as the reflection of their progress to reach goals.

From all the characteristics of the aspects mentioned, namely: writing achievement, teaching technique (thematic patterning technique and conventional technique), and achievement motivation, indicates all of the aspects closely relate to each other and also explain the phenomenon of this research. Thematic patterning technique provides great chance for the students to create creative writing since it provides chance for the students look at the progression of information or ideas in their writing. Thematic patterning technique emphasizes on the process to produce qualified writing products is appropriate for the high achievement motivated students. The characteristics of high achievement motivated students are suitable with characteristics of creative students who like new information (feedback) to inspire their writing. At the end, it can be concluded that creativity develops well through thematic patterning technique. The students who have high achievement motivation can reach optimum writing achievement if they are taught by using thematic patterning technique.

\section{CONCLUSION}

Based on the research findings discussed above, it is concluded that teaching technique, thematic patterning technique and conventional technique, and achievement motivation affect significantly on students' writing achievement.

There is a significant difference on students' writing achievement between the students who were taught by using thematic patterning technique and conventional technique. Students' writing achievement taught by using thematic patterning technique is higher than those taught by using conventional technique 
There is a significant interaction between teaching technique (thematic patterning technique and conventional technique) and achievement motivation on students' writing achievement

There is a significant difference on students' writing achievement between the students with high achievement motivation who were taught by using thematic patterning technique and conventional technique. The students with high achievement motivation who were taught by using thematic patterning technique $(X=87.051308)$ showed higher achievement than those with conventional achievement $(\mathrm{X}=74.615385)$.

There is a significant difference on students' writing achievement between the students with low achievement motivation who were taught by using thematic patterning technique and conventional technique. The students with low achievement motivation who were taught by using thematic patterning technique $(X=80)$ showed higher achievement than those with conventional achievement $(\mathrm{X}=71.965769)$.

There is a significant difference on students' writing achievement between the students with high achievement motivation and the students with low achievement motivation taught by using thematic patterning technique. The students with high achievement motivation taught by using thematic patterning technique ( $X=87.051308)$ showed higher achievement than the students with low achievement motivation taught by using thematic patterning technique $(X=80)$

There is a significant difference on students' writing achievement between the students with high achievement motivation and the students with low achievement motivation taught by conventional technique. The students with high achievement motivation taught by using thematic patterning technique ( $\mathrm{X}=74.615385)$ showed higher achievement than the students with high achievement motivation by thematic patterning technique $(X=71.965769)$

\section{REFERENCES}

Abisamra, N. 2002. Affect in Language Learning: Motivation Available at http://nadabs.tripod.com/ Accessed on $24^{\text {th }}$ October 2014

Alonso, I and McCabe, A. Improving text flow in ESL Learner Composition. Madrid. TESL Journal. $9(2)$

Campbell, Allen. 2002. Freewriting Techniques. Copyright Lynchburg College: Online Source.

Cakraverty, A. and Gautum K. 2000. Dynamic of Writing. Available at http://exchanges.state.gov/forum/vols38/no3/pp22.htm. Accessed on $5^{\text {th }}$ February 2014

Downing, A. 2001. Thematic progression as Functional Resource in Analysis Texts. Madrid. adowning@,filol.ucm.es http://www.ucm.es/info/circulo/no5/downing.htm Accessed on $24^{\text {th }}$ December 2014

Gardner, R. C. 2001. Language Learning Motivation, The Students, The Teacher and The Researcher. Available at http://publish.uwo.ca/ gardner/. Accessed on $27^{\text {th }}$ September 2014

Jing, W. 2015.Theme and Thematic Progression in English Writing Teaching. Journal of Education and Practice. 6(21). 178-187

Marhaeni. 2005. Pengaruh Assessment Portfolio dan Motivasi Berprestasi dalam Belajar Bahasa Inggris Terhadap Kemampuan Menulis dalam Bahasa Inggris. Unpublished Dissertation: Program Pascasarjana Universitas Negeri Jakarta.

Rustipa, K. 2012. Theme Rheme Organization of Learners' Texts. Jurnal Dinamika Bahasa dan Ilmu Budaya. 4(1). 1-17 